\title{
THE USE OF SONGS IN INCREASING STUDENTS' UNDERSTANDING OF FIGURATIVE LANGUAGE
}

\author{
Salwa, Ayu Liskinasih \\ University of Kanjuruhan Malang, Indonesia \\ (salwa@unikama.ac.id; ayuliskinasih@unikama.ac.id)
}

Received: $07^{\text {th }}$ March 2016; Revised: $17^{\text {th }}$ May 2016; Accepted: $28^{\text {th }}$ June 2016

\section{ABSTRACT}

This study aims at investigating the perceptions of students at Kanjuruhan University of Malang about the use of songs as supplementary materials in understanding the meanings of figurative language such as metaphor, hyperbole, personification, etc. This study employed a mixed-methods approach. The data were collected through questionnaire, video-recording and focus-group discussion. The participants of this study were 30 students attending vocabulary class in the third semester. The results of this data analysis showed that most of the students $(85 \%)$ have positive attitudes towards the use of songs as considerable media to help them understand the meanings of figurative language and improve their motivation in learning English. It is hoped that English lecturers will use songs as one of interesting techniques in teaching figurative language, so that students will be more interested in analyzing figurative language using authentic-based materials.

Key Words: figurative language; songs; vocabulary

\begin{abstract}
ABSTRAK
Penelitian ini bertujuan untuk mendeskripsikan secara rinci bagaimana pembelajaran bahasa kiasan (figurative language) seperti metafora, hiperbola, personifikasi, dsb agar dapat lebih mudah dimengerti oleh para mahasiswa, melalui media lagu sebagai materi tambahan (supplementary materials). Metode penelitian ini adalah mixed-method. Peneliti menggunakan beberapa instrumen penelitian yaitu kuesioner, observasi, rekaman video dan juga focus- group discussion yang dilakukan pada para participant yaitu 30 mahasiswa semester tiga yang menempuh mata kuliah Vocabulary pada jurusan pendidikan Bahasa Inggris Universitas Kanjuruhan Malang. Hasil dari penelitian ini menunjukkan bahwasanya para mahasiswa (85\%) memiliki persepsi dan sikap yang positif terhadap penggunaan lagu dalam pembelajaran Figurative language. Pembelajaran dengan menggunaan media lagu ini juga dapat meningkatkan motivasi mahasiswa dalam mempelajari Figurative language. Penelitian ini secara teori dapat menambah variasi metode pembelajaran Figurative language sehingga diharapkan para dosen pengajar mata kuliah vocabulary serta mata kuliah Intro to literature (pendekatan sastra) dapat menerapkan metode ini didalam kelas sehingga dapat meningkatkan motivasi mahasiswa dalam mempelajari bahasa Inggris sebagai bahasa asing melalui media otentik seperti lagu.
\end{abstract}

Kata Kunci: figurative language; lagu; vocabulary

How to Cite: Salwa. Liskinasih, A. (2016). The Use of Songs in Increasing Students' Understanding of Figurative Language. IJEE (Indonesian Journal of English Education), 3(1), 75-88. doi:10.15408/ijee.v3 i1.3443

Permalink/DOI: http://dx.doi.org/10.15408/ijee.v3i1.3443 


\section{INTRODUCTION}

Vocabulary mastery plays a significant role in developing learner's language competence. Some considerable linguists have claimed the importance of vocabulary mastery in the process of Second Language Acquisition (SLA). According to Cook (2003), grammatical knowledge itself does not guarantee the students could use the Target Language (TL) to socially function, particularly in the actual use of the TL in daily communications in which vocabulary mastery is absolutely needed. Despite the significant role of vocabulary, previous studies on university students' ability in vocabulary acquisition showed low competency on vocabulary mastery. Cahyono and Utami (2008)' study contented that vocabulary is not frequently taught at the university level since it is only applied in some topics based on the curriculum in English Education Department. In addition, some studies showed that students had a low competence in vocabulary, predominantly in the area of figurative language (Utami, 2012) Furthermore, many English lecturers only focus on the teaching of grammar and pronunciation; consequently, students found difficulties in applying and understanding English vocabularies particularly figurative languages used in the literary work, such as poems, novels, or films.

So far, in some classes, particularly in the EFL settings, figurative language is either ignored or treated as if it was a very difficult topic since it has illiteral meanings and unusual symbols, and provide combination of words that have a new perspective and meanings on the word as well. However, so far the teaching method used is considered as a conventional way by using constructed materials such as modules, books, therefore the use of songs may help enrich students' vocabulary particularly in the figurative language ones.

Figurative language is language deflection to create certain and rhetorical effects or special meanings (Shen, 2009), for example:

\section{"It rains cats and dogs"}

It means a heavy rain. There is no relationship with animals in this case cats and dogs.

There are many kinds of figurative language such as metaphor which is a figure of speech that makes a comparison between two things that are basically similar. Personification is a figure of speech where human qualities are given to animals. Hyperbole is the use of exaggeration as a rhetoric device of figure of speech. While simile is a 
figure of speech that directly compares two things by using connecting words-as or like.

Considering that the teaching of figurative language is not easy, therefore English lecturers should apply more interesting teaching strategies, for example by using songs as media. It is hoped that authentic materials like songs are more frequently used as supplementary materials, so that students may learn English and having fun simultaneously.

Many previous studies show positive impacts of songs in increasing students' vocabulary acquisition, particularly in understanding literary works. Shen (2009) claimed that the use of songs reduced students' stress in learning the transferred meanings or figurative language; therefore, songs can increase students' self-confidence in learning English. Hunt and Beglar (as cited in Cahyono and Widiati, 2011) added that there are three considerable strategies in the vocabulary acquisition: direct, indirect and independent strategy learning. From those three strategies, the independent strategy learning is considered as the most crucial one as it gives opportunities for students to learn vocabulary autodidactically or outside the classrooms. One of the remarkable strategies is by listening to songs. In addition, according to Krashen (as cited in Nunan, 1999), learning figurative language through song is regarded as one of the subconscious acquisition. In this process, students increase their vocabulary mastery unintentionally while they enjoy doing daily activities. Hence, students will not only focus on the grammatical aspects as they do when they are doing a conscious learning. This notion is strengthened by Pusporini's study (2013) which also showed that songs have positive influences towards students' vocabulary enrichment since students can learn a foreign language in a more natural way.

In this study, the researchers tried to analyze the perceptions of students on the use of songs in learning figurative language. This is important since the result of this study will help the researchers to know how the use of songs might help students learning figurative language from their perspective-different from the preceding studies which tried to prove the effectiveness of the strategy.

\section{METHOD}

This is a mixed-method research as the researchers combined both qualitative and quantitative technique to gather the data. To know students' 
perceptions on the use of songs in learning Figurative language, the researchers employed a set of survey which belongs to quantitative data collection technique. In addition, to get deeper meaning from students' survey answers, the researchers also collected qualitative data from Focus Group Discussion (FGD). Furthermore, to complete the data, the researchers collected information from classroom observation. This observation helped the researcher to relate students' survey answers with the teaching learning situations (Latief, 2012).

The participants of this study were 30 students at the Department of English Education, University of Kanjuruhan Malang. They were attending the vocabulary course in the second semester. In this study, the participants were divided into several groups. Each group was asked to present an analysis of figurative language represented in songs. The steps of the presentation were listening to the songs and analyzing the figurative language found in the lyrics.

\section{FINDINGS AND DISCUSSION}

Questionnaire results on students' perception upon figurative language learning through songs showed strong positive attitudes. These results can be summed up from students' questionnaire answers which consist of fifteen questions related to their perceptions on the use of song technique in learning figurative language.

The Diagram 1 shows that almost half of the students (14 students or $46 \%$ ) strongly agreed that they like learning English through song. Furthermore, 14 other students (46\%) also agreed to the same notion. Thus, it can be understood that almost all of the students enjoyed the teaching and learning process using songs as instructional media.

Diagram 1. Column Chart on the First Question Answers

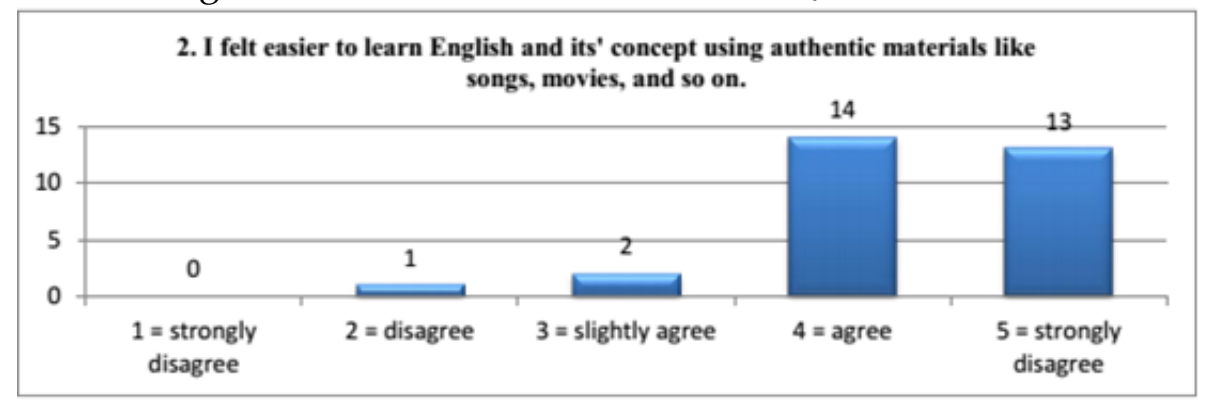


It can be seen from the students could comprehend the Diagram 2 that around $47 \%$ concept of figurative language by respondents (14 students) agreed only reading text books. The that it was easier for them to learn English and its' concept through authentic materials like songs or movies. The other 13 students (43\%) even strongly agreed to this statement. Therefore, it can be inferred that almost all students enjoy learning English through authentic materials.

From the Diagram 3, it is majority of the students $(40 \%$ or 12 students) were slightly agreed to this notion, while $17 \%$ respondents (5 students) agreed with this notion. This variety shows that each student has different style of learning; thus, providing an assortment of instructional techniques will facilitate experience on numerous learning styles. interesting to know that $37 \%$ of the students (11 students) disagreed over the statement asserting that

Diagram 2. Column Chart on the Second Question Answers

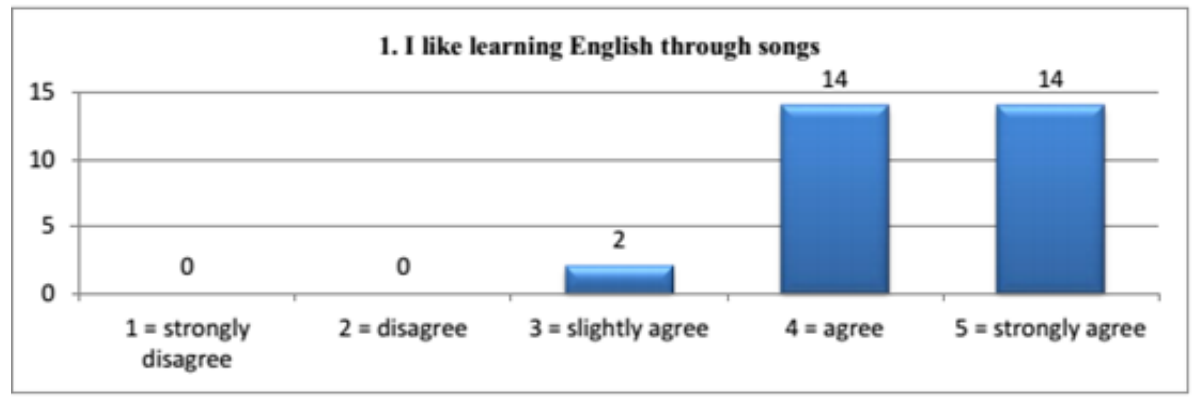

Diagram 3. Column Chart on the Third Question Answers

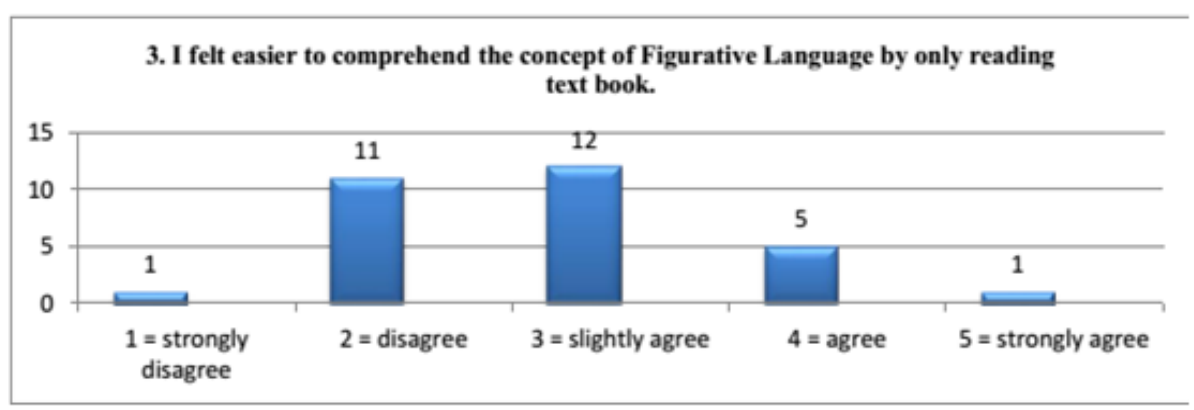


Diagram 4. I could understand the concept of figurative language better when it was taught using songs as instructional media.

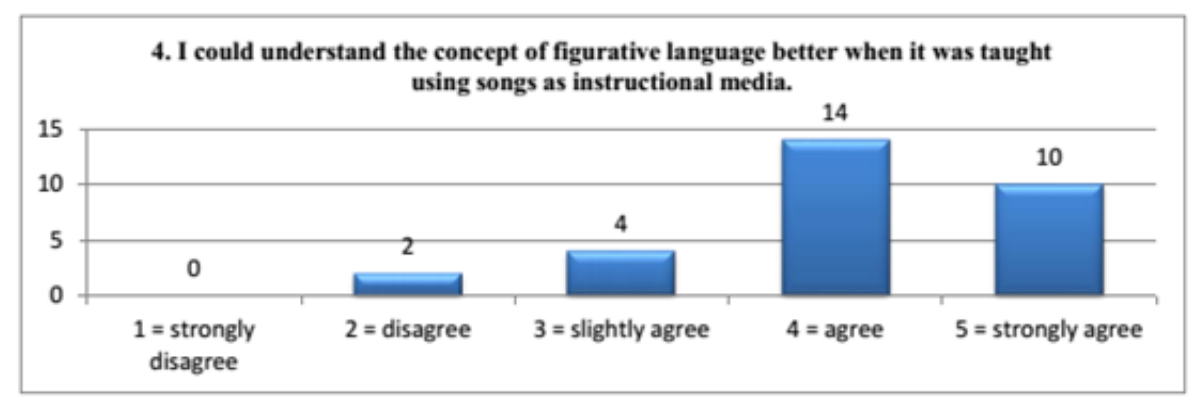

Diagram 5. Column Chart on the Fifth Question Answers

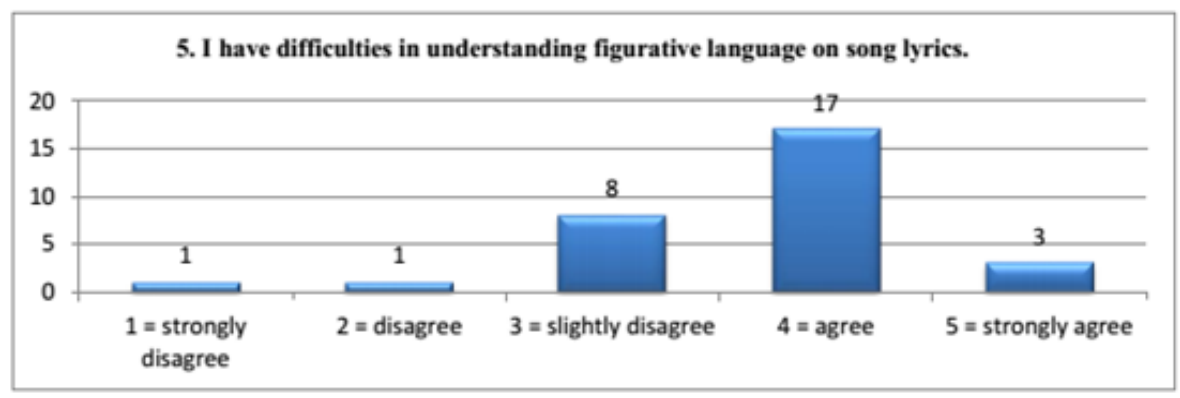

The Diagram 4 shows students' positive perceptions on the use of songs as media in the teaching of figurative language. Here $47 \%$ students (14 people) declared their agreement over the statement affirming that they could easily comprehend the concept of figurative language when it was taught using songs. Moreover, 33\% other students (10 people) even strongly agreed to this statement. Hence, it can be said that the majority of the class enjoyed using songs in learning figurative language.
From the Diagram 5, it can be seen that, unfortunately, 57\% of total respondents (17 people) agreed to the statement that they had difficulties in understanding figurative language on song lyrics. This number suggests that even if songs could be an enjoyable instructional media, yet understanding figurative language in song lyrics was still considered as a challenging task.

The Diagram 6 suggests that more than half (57\%) of all students (17 people) affirmed their agreement and the other 9 people (30\%) even 
strongly agreed that the task of analyzing figurative language in song lyrics helped them gaining better comprehension on the meanings of figurative language. It can be understood since the task provided immediate practice to understand the topic. Surprisingly, no one $(0 \%)$ in the class declared that they disagreed with this statement.

The result of the seventh question answers in Diagram 7 reveals that almost half $(47 \%)$ of all total respondents (14 people) agreed that they preferred working in group than working individually when analyzing figurative language in song lyrics. Additionally, ten other students (34\%) also strongly agreed to this statement. In other word, the majority of the students enjoyed working in groups when accomplishing the task.

Talking about group members, Diagram 8 shows that around $45 \%$ students (13 people) were in agreement to mention that their peers were very supportive to help comprehending concepts and finding examples of figurative language; especially on their analyzed song lyrics. On the other hand, no one mentioned their disagreement over this statement. These findings suggest that the learning of figurative language is easier to be done in group since the students can share their knowledge and discuss the meaning of figurative language together.

Diagram 6. Column Chart on the Sixth Question Answers

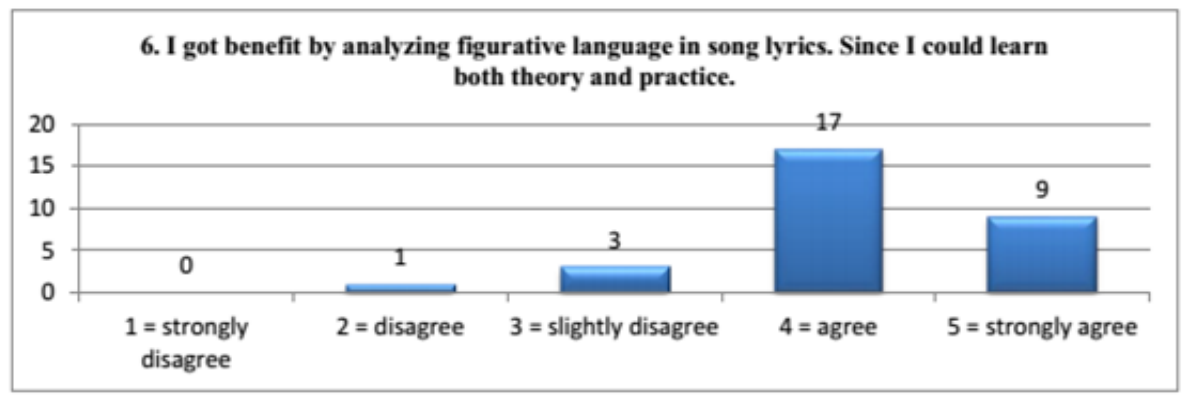


Diagram 7. Column Chart on the Seventh Question Answers

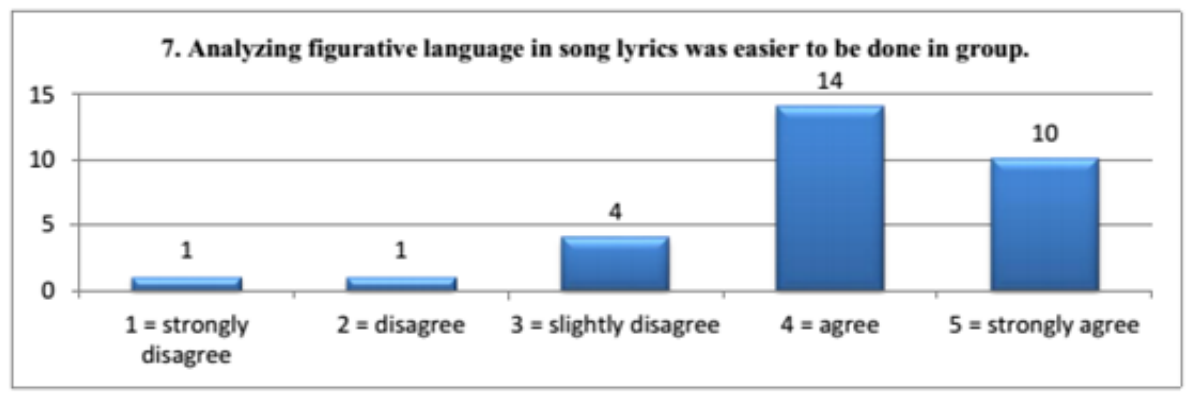

Diagram 8. Column Chart on the Eighth Question Answers

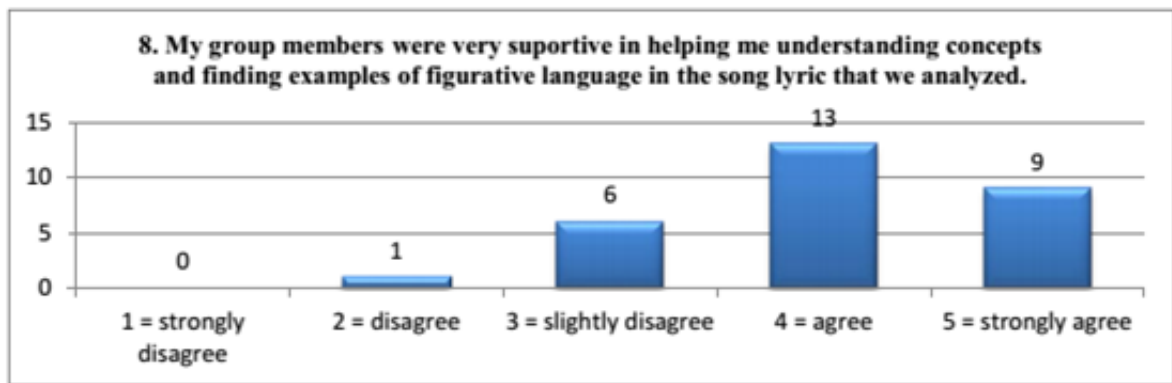

Diagram 9. Column Chart on the Ninth Question Answers

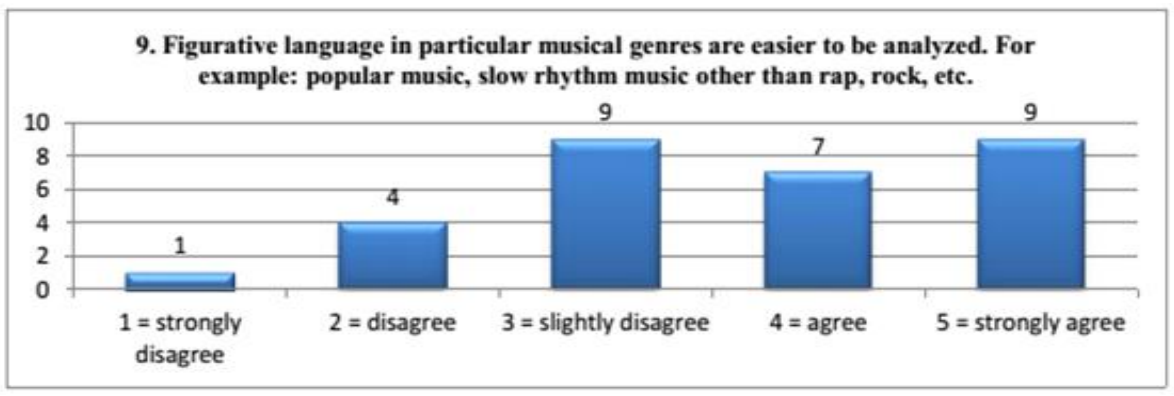

Another interesting fact related to music genres used in the instruction is shown in Diagram 9. Here the students shared various reactions over the statement that suggests figurative language in certain musical genres is easier to be analyzed; such as popular music or slow rhythm music other than rap or rock. In fact, $30 \%$ of the students (9 people) said they are strongly agreed, $23 \%$ (7 people) agreed to the statement, other $30 \%$ (9 people) slightly agreed to the statement, while only $2 \%$ (4 people) disagreed. This finding related to the fact that each student has their own musical preference. Thus, as long as they can 
enjoy the music, it would be possible to use any musical genre in the students' analysis.

The Diagram 10 explains students' perception on learning figurative language by listening to the result of other group analysis in class presentation. Around $40 \%$ of the student (12 people) agreed that they can easily understand other group explanation; while 33\% other (10 people) slightly agreed to the notion. This result shows that most of students find it easier to understand figurative language when it is put in the context. Here, in the classroom presentation, the students not only presented merely about the meaning of figurative language in their song, but also connected the meaning to the overall context, theme, or tone of the song.

Compared to other media, most students agreed that learning figurative language through songs is easier. It can be seen from the Diagram 11 that shows $17 \%$ students strongly agreed to the statement; $37 \%$ or most of the students agreed to the statement; and $36 \%$ other slightly agreed to this notion. Figurative language used in songs is usually less than what we can find in movie or novel, yet it is used effectively in provided context.

Next, Diagram 12 tells us about students' perception on their advanced understanding of the concept after teacher's follow up. The pie chart in Diagram 12 shows that most of the students be in agreement that their teacher's follow ups were very helpful in advancing their understanding. In other word, a good technique will work better by teacher's supports and it's beneficial in building students' stronger comprehension.

In Diagram 13, we can see the optimism of the students to be able to analyze figurative language on song lyrics other than the one that they did as assignment. This data means that teaching figurative language using song is not only enjoyable for the students but also great to foster students' selfconfidence and autonomy in learning.

The other proof that students were getting more confidence in applying their comprehension is shown in Diagram 14. Here, almost all of the students agreed to the notion that they can make use of the figurative language examples from the song that they analyzed on their oral/ written communication in English. This data 
shows us that figurative language examples in songs are easy to be might also be easy for them to use it in memorized and understood, thus, it other contexts.

Diagram 10. Column Chart on the Tenth Question Answers

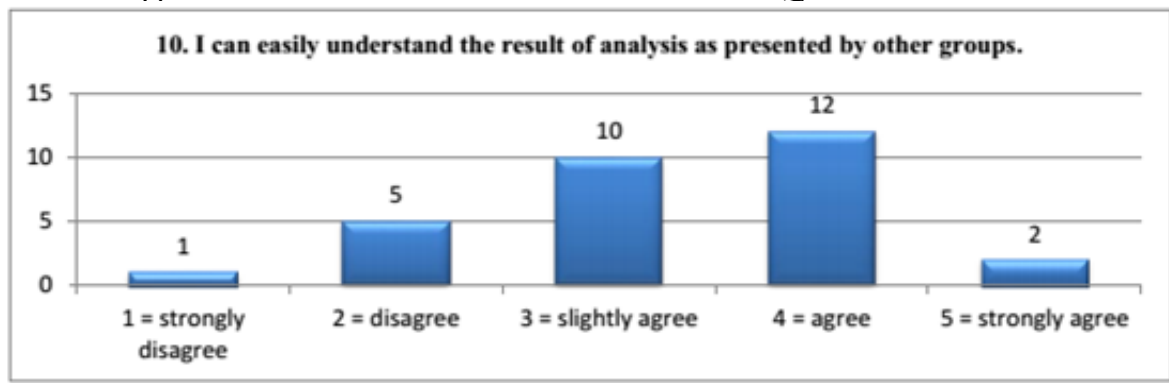

Diagram 11. Column Chart on the Eleventh Question Answers

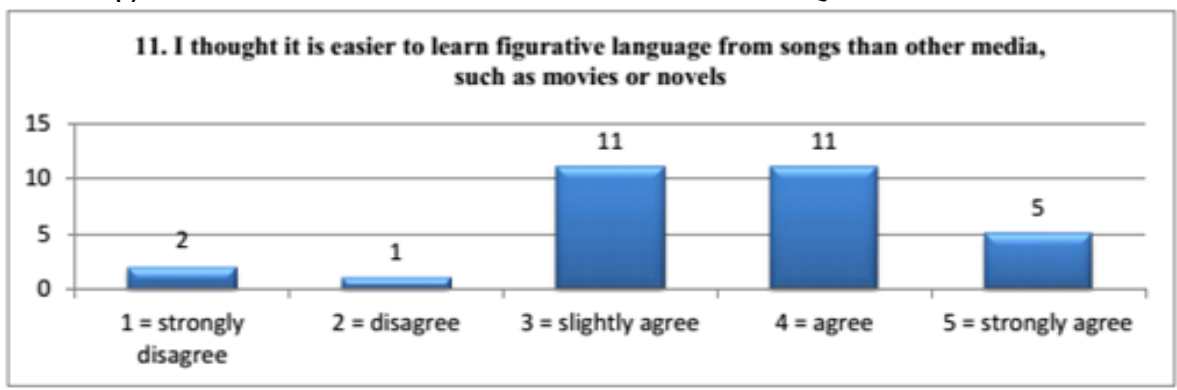

Diagram 12. Column Chart on the Twelfth Question Answers

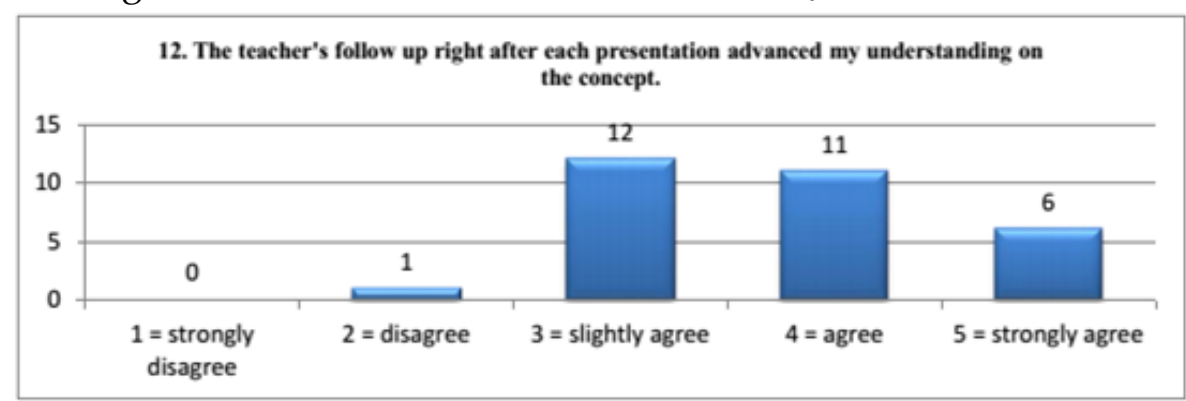

Diagram 13. Column Chart on the Thirteenth Question Answers

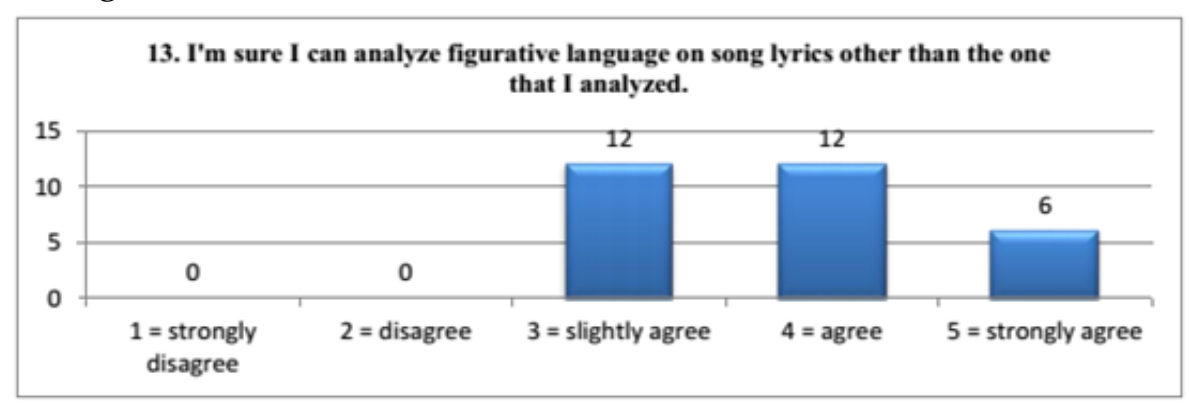


Diagram 14. Column Chart on the Fourteenth Question Answers

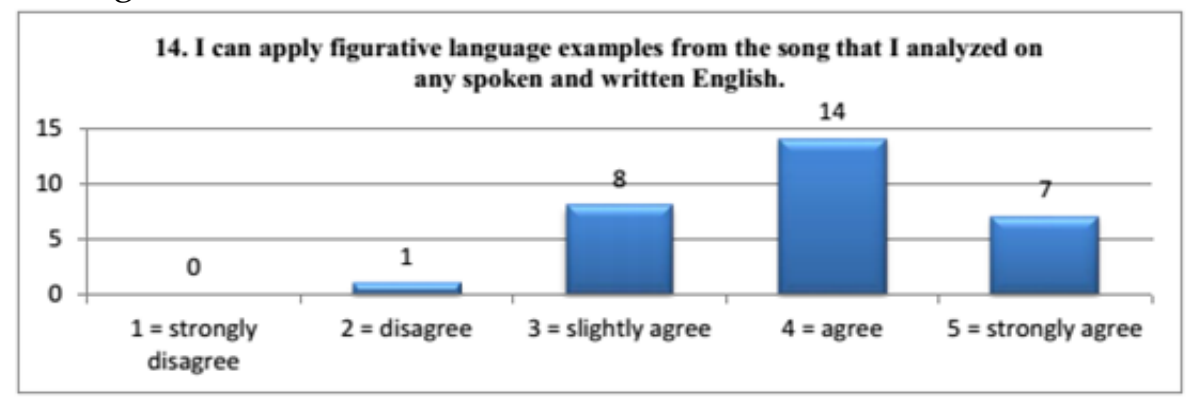

Diagram 15. Column Chart on the Fifteenth Question Answers

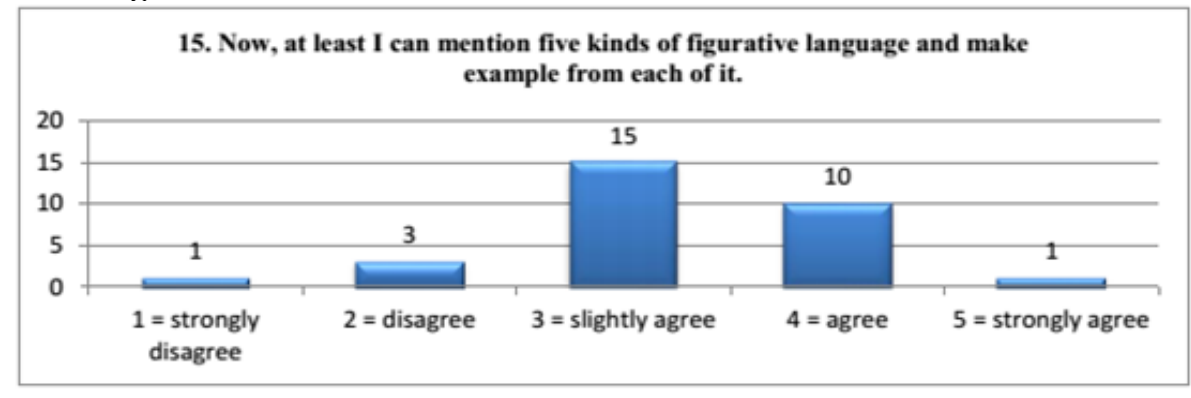

The last data in Diagram 15 shows similar results to Diagram 13 and 14. From the students' answers, it is known that most of the students believed they can mention at least five kinds of figurative language and make example from each of it after they learned it through song lyric analysis.

These positive results were supported by the data collected through classroom observation and focus group discussion. Before the questionnaire was designed, the researchers conducted one month classroom observations to see how the class was organized and what activities were conducted in the classroom. The observation instrument used was the Classroom Observation Schedule
(Good, 2000) and the classroom observation was done in $\max 60$ minutes in length. The researchers conducted classroom observation since the process of education can be observed in more naturalistic settings and also it provides more detailed and precise evidence than other data sources (Good, 2000).

Furthermore, from the video recording, the researchers saw that the students were very active and well prepared in presenting their analysis. The focus group discussions were done right after the classroom presentations. This Focus Group Discussion (FGD) is used as a qualitative approach to explore data about students' perceptions, opinions, and attitudes 
towards the use of songs in the teaching and learning of Figurative language (Creswell, 2009). In this FGD, the researchers applied three stages, namely planning, interviews and analysis of the data. The benefits of conducting Focus Group Discussion is the researcher can also compare results among different groups (Freitas, 1998).

The results of the FGD showed that the students agreed with the statement that songs helped them to understood figurative language in an enjoyable way. They could pick their favorite songs and learned the implicit meanings of the lyrics from its' figurative language. The students also said that the traditional way of learning figurative language was boring and hard to be comprehended because it was only theories on the text books. Furthermore, learning figurative language through songs was also increasing the students' learning motivation. Figurative language is used to be considered as a tricky topic since the students have to learn implicit meanings using symbols; which was quite hard to be understood. Thus, the songs' lyrics give the students a clearer context or situation to help them understand the meaning of figurative language.

\section{CONCLUSION AND SUGGESTION}

The result of this study showed that the students have positive perception and attitude on the use of songs in learning figurative language. Using songs was proven to be successfully increased students comprehension, motivation, selfconfidence, and autonomy in learning figurative language.

It is suggested from the result of this study that teacher can employ similar technique to teach figurative language. It is expected that the students will also be more motivated and comprehend the concept more easily. For further researcher, it is also important to study the employment of other authentic materials in the teaching of figurative language; for example, using novels, movies, YouTube videos, or other sources. Further researcher can also utilize these materials and compare its effectiveness. This study is needed to know which supplementary materials might be the most successful in facilitating the teaching and learning process.

\section{REFERENCES}

Creswell, J.W. (2009). Research design: Qualitative, quantitative, and mixed methods approaches. Thousand 
Oaks, California: SAGE Nunan, D. (1999). Second language Publications, Inc.

Cahyono, B.Y., \&Widiati, U. (2011).The teaching of English as a foreign language in Indonesia. Malang: State University of Malang Press.

Cook, G. (2003). Applied linguistics.Oxford: Oxford University Press.

Cahyono, B.Y \& Widiati, U (2008). The Teaching of EFL vocabulary in the Indonesian context. TEFLIN Journal. The State of The Art. 19(1).1-17.

Freitas, H. (1998). The Focus Group, a Qualitative Research Method, Journal of Education. 1(1), 1-22.

Good, T . (2000). Looking in Classrooms. teaching and learning. Boston: Heinle.

Pusporini, R. (2012). Teaching English genre through songs. A paper presented at the 59th TEFLIN international conference. Widya Mandala Catholic University Surabaya. 6-8 November 2012.

Shen, C. (2009). Using English songs: An enjoyable and effective approach to ELT.English Language Teaching Journal. 2(1), 88-94.

Utami, I.L.P. (2012). Profil masalahmasalah pembelajaran pada perkuliahan poetry. Jurnal Pendidikan dan Pengajaran. 45 (3), 210-219.

New York. Longman.

Latief, M.A. (2012). Research methods on language learning: An introduction. Malang: UM Press. 